\title{
The Venture Capital Certification Role In Initial Public Offerings
}

Tarek Miloud, INSEEC Business School, France

\begin{abstract}
Using high frequency Euronext Paris data, the paper examines the market microstructure trading characteristics of venture backed initial public offerings (IPOs) in the French market. Previous North American market studies approve the role played by venture capital (VC) firms for the certification of IPOs and their role in reducing the asymmetric information between investors. The study sample is composed of IPOs realized during the period 20002013 both with and without VC firm involvement. The results present no significant price difference between both IPO types. The cost of asymmetric information and of price volatility is higher for the VC-backed operations. Moreover, the study shows that underpricing is positively correlated to the cost of the information asymmetry. Contrary to previous studies, the results show that the effects of VC firm certification and monitoring are not perceived by IPO investors in the French market.
\end{abstract}

Keywords: Venture Capital; Asymmetric Information; IPO; Market Microstructure

\section{INTRODUCTION}

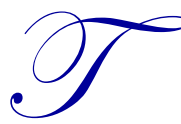

he initial public offering (IPO) process is known for its asymmetric information between investors: the firm insiders have easier access to private information than the individual investors. To reduce this asymmetry and to ensure the IPO success, a third party stakeholder should oversee the process. Wang, Wang and Lu (2003) confirm that venture capital (VC) certification is the best way of achieving this for two reasons. First, the $\mathrm{VC}$ firms have reliable information on the issuing firm because, being members of the board of directors, they benefit from special working relations with the issuing firm's team of directors, unlike the other financial intermediaries. Second, the VC firms have to verify false certification to ensure that they preserve their reputation.

Apart from their certification role, the $\mathrm{VC}$ firms also have a monitoring role in the firms that they finance. Because of their numerous investments, they are encouraged to use diverse methods to supervise or to verify opportunist behavior in these firms. According to Barry, Muscarella, Peavy and Vetsuypens (1990), Megginson and Weiss (1991), Jain and Kini (1995) and Brav and Gompers (1997), the certification and monitoring roles during an IPO can increase the value and improve the operational and financial performance of issuing firms in the medium to long term. However, numerous research studies have shown that VC firms have a negative effect on these operations. Amit, Brander and Zott (1998) identified an adverse selection problem where the less experienced entrepreneurs ask the $\mathrm{VC}$ firms to share the risk, whereas the more experienced ones manage their firms without requesting outside finance. Consequently, the firms with VC may perform badly because of information asymmetry. Gompers (1996) suggests a 'grandstanding' hypothesis on the part of young VC firms, where they are encouraged to reveal their abilities too soon to potential investors by assisting the firms with their portfolio in the financial markets. Therefore, they may find that they perform badly because of a lack of IPO experience. Generally during the IPO, either the adverse section effects or grandstanding aggravate the information asymmetry problem between the initiates and the individual investors.

The existing empirical studies generally use accounts data. Our approach differs; we use microstructure measures from the markets including bid-ask spreads. This information asymmetry and the volatility component should be studied when investigating whether the participation of a VC firm contributes to reducing the information asymmetry during the IPO process. The markets microstructure literature shows that the spread and the volatility of prices increase according to the information asymmetry that exists between the insiders and the outsiders. The 
certification/monitoring effects are stronger than the effects of adverse selection/grandstanding; however, reducing information asymmetry in the financial marketplace would consequently diminish the spreads and the price volatility for the IPOs financed by the VC firms. However, if the effects of certification and monitoring are dominated by the effects of adverse selection and grandstanding, then the spread and the price volatility become too high. Moreover, the pricing and disclosing information process during a VC-backed IPO could be clarified by examining the microstructure data in the financial markets because, according to O'Hara (1999) and Madhavan (2000), the negotiation mechanism and the structure regulating the stock markets both have an effect on investor behavior.

I chose to investigate the French market, a market with a two-decade VC history and with few existing studies analyzing the role of VC firms in the French market. The empirical results show that the effective relative spreads, the cost of information asymmetry and the volatility of the IPOs financed by VC firms are not more reliable than other classic operations. Their degree of information asymmetry perceived by the market is not therefore inferior to that of other operations. The effect of certification/monitoring by $\mathrm{VC}$ firms is no more marked than that of the adverse selection/grandstanding. Although both effects exist, the positive effects of the certification/monitoring of a venture-backed IPO are largely counterbalanced by the negative effects of adverse selection/grandstanding.

The paper is organized as follows: sections 2 examine the literature on the underpricing of IPOs and the VC firm role in certification/monitoring and in adverse selection/grandstanding. The markets microstructure literature relative to information asymmetry, to bid-ask price spreads, and the costs of information asymmetry and price volatility is also briefly presented. We introduce the selected test hypotheses. Section 3 then describes the data and the research methodology used in this study. Section 4 summarizes and discusses the empirical results, and finally section 5 presents the conclusions.

\section{RELATED LITERATURE AND PREDICTIONS}

\subsection{Certification Theory and the Role of VC Firm}

Booth and Smith (1986) certification theory holds that the VC firm is best informed about the future potential and the correct value of the firm that it is financing, and that its role consists in certifying that the subscription price perfectly reflects the information in its possession. Certification is therefore a means of reducing the degree of information asymmetry and consequently reducing the underpricing.

Within the context of a principal agent model with a moral hazard and hidden information, two types of information (hard and soft) can be distinguished. According to Stein (2002), hard information - such as that published in accounts documents and in the IPO prospectus - is quantitative and is verifiable by outsiders. In contrast, soft information (pertaining to the investment decision) is of a qualitative type and is not verifiable (by any person other than the agent who produced it). It is therefore more easily manipulated, but also more detailed and more precise than hard information. Megginson and Weiss (1991) confirm that the VC firm is able to certify the IPO because it uses the reputation that it has built up during its financing of the firm. Therefore, it can maintain a durable relationship with the fund managers and the institutional investors who both finance the funding and who are potential purchasers during the IPO. The certification generally aims to reduce the information asymmetry between the insiders and the firm outsiders.

Gompers and Lerner (2004) indicate that VC firms are specialized in collecting and evaluating information on innovative firms with strong growth potential and that they are capable of overcoming the problem of information asymmetry that emerges during an IPO process. Tirole (2006) confirms that the presence of well-informed agents, such as commercial banks or VC firms, can certify the IPO and can reduce the information asymmetry. The certification agent must know the correct value of the firm and should inform potential investors of this. Consequently, an IPO financed by a VC is more successful than other IPOs because of the VC's certification and/or monitoring role, and the investors in the financial market anticipate an underpriced subscription.

Barry et al. (1990) agree that a VC, during an IPO, provides rigorous and regular firm monitoring, thereby making it possible to reduce agency costs and to underprice the subscription. Jain and Kini (1995) conclude that the presence 
of a VC gives a positive signal regarding the firm's quality that results in an improvement in the post IPO operational performance. Notably, the information asymmetry situation does not only exist between insiders and outsiders, it is also to be found between entrepreneurs seeking external financing and VC firms. Amit et al. (1998) consider that the best projects are those that are self-financed by the VC firms. Less experienced entrepreneurs have a tendency to involve VC firms in their investment projects. Consequently, the venture-backed firms are of a mediocre quality because of the information asymmetry. Apart from the adverse selection effect, Gompers (1996) confirms the grandstanding hypothesis for young $\mathrm{VC}$ firms since they are motivated by seeking an improvement in their reputation in the financial market to facilitate new fundraising. Consequently, there is a strong impetus for young $\mathrm{VC}$ firms to make it known in the financial market that they have the experience necessary for handling IPO operations correctly. Sahlman (1990) considers that a credible certification requires verifying three things: (1) overpriced operations damage reputations; (2) the gains procured by a false certification are negligible compared with the good image created over a period of time; and (3) the issuing firm must incur the cost of a reputable certification agent; i.e. the certification process is not cheap. VC firms are strongly motivated to preserve their reputation to guarantee access to sources of financing with very favorable conditions that make them more attractive to entrepreneurs.

Wang, et al. (2003) corroborated the grandstanding hypothesis by studying the relation between the performance of startups and the participation of VC firms. This theory holds that the VC firms have a similar role to that of majority shareholders. They are implicated in the management and the recruitment of key personnel and provide assistance in the production process and even in developing the supplier and client relationship. The role of a VC firm during an IPO is outlined as follows: outsiders are uncertain of the quality of information relating to the firm, while the presence of a VC firm implies to the financial market that the firm is of a high quality, thereby reducing the level of information asymmetry. However, if an adverse selection and/or grandstanding problem exists, then the participation of a VC firm has no bearing on the quality of the firm. Information asymmetry is therefore weaker if the effects of certification/monitoring are stronger than the effects of adverse selection and/or grandstanding. However, during an IPO, although the effects of adverse selection and/or grandstanding are stronger than the effects of certification/monitoring, the degree of information asymmetry between the insiders and the outsiders for IPOs financed by $\mathrm{VC}$ firms is higher.

\subsection{Certification and IPO Underpricing}

Ritter and Welch (2002) and Loughran and Ritter (2004) confirm that IPO underpricing is observed even in the most efficient markets and several frameworks have attempted to explain this phenomenon. They distinguished three theoretical trends: (i) the impact of institutional incentives; (ii) the effect of changes in the ownership and control structure; and (iv) the existence of information asymmetry during IPOs.

In conformity with the certification hypothesis, Megginson and Weiss (1991) and Barry, et al. (1990) showed that IPOs with VC firm involvement present a larger degree of underpricing than for those not involving VC firms. In contrast, Francis and Hasan (2001), Peggy and Wahal (2004) and more recently Arikawa and Imad'eddine (2010) and Elston and Yang (2010) found that IPOs without VC firm involvement show higher underpricing than those financed by VC firms and question the certification hypothesis, rekindling the debate on the subject. Peggy and Wahal (2004) tested the certification hypothesis using the samples of Megginson and Weiss (1991) and Barry, et al. (1990) and noted no significant difference in the level of underpricing between the two means of financing. Consequently, because of the transfer of assets and the commissions borne during the IPO, the cost of such an operation financed by $\mathrm{VC}$ firms is much lower than one not financed by $\mathrm{VC}$ firms. The question then arises as to why VC firms in particular bear such costs. Loughran and Ritter (2002) showed that VC firms acquire underpriced IPO securities to later resell them with large secondary gains. Gompers (1996) pointed out that a VC firm is subjected to liquidity constraints when it reimburses investors and that the IPO helps it to create a good investor image that in turn enables it to raise more capital for future investments.

Neither explanations is convincing as the first refers to a speculative bubble in the 2000 s, whereas underpricing is a persisting phenomenon that is independent of the period. The second explanation is not valid for all VC firms, particularly the youngest ones. Moreover, it is based on the American finance system, where VC firms are more experienced because of the large number of IPOs in that market. To reconcile these two explanations, Rossetto 
(2008) recognized that the IPOs with VC firm involvement are distinguished by higher underpricing during the normal period and by overpricing during the so called 'hot' periods. To overcome the irregularity of empirical underpricing results, Rossetto (2013) proposed a theoretic model that depends on the period of issue. During a hot period, there are considerable opportunities for profitable investments and VC firms are motivated to recover their invested capital to reinvest in new projects. In normal periods, the VC firms try to maximize the yield from the projects in their portfolios during an IPO.

Chemmanur and Krishnan (2012) reexamined the role of VC firms and conclude that underpricing is not appropriate for measuring the role of the $\mathrm{VC}$ firms and propose a third explanation as an alternative: the IPO price ratio/the intrinsic value. Using this variable, they show that the role of a VC firm is not only to certify the value of the IPO, but above all, to play a commercial role in their contacts with the other players in the financial market. The presence of a VC firm helps all of the shareholders to obtain the maximum from the product generated by the transfer of securities, and it can crucially attract serious firm purchasers who have a solid reputation.

\subsection{Research Hypotheses}

IPO information asymmetry can be measured by the bid-ask spread. The more uncertain the value, the larger the bid-ask spread will be. Many studies have modelled the remuneration of the market makers for information asymmetry risks with the aid of a bid-ask spread. The purchasing price is always lower than the sales price; this enables a profit to be made for each purchasing-selling operation. Copeland and Galai (1983) and Glosten and Milgrom (1985) proposed theoretic models linking the bid-ask spread and the level of information asymmetry.

These models assume that the market makers expect to make losses during negotiations with an informed trader; this is the reason for the wide bid-ask spread. However, if the exchanges are made with a 'noise trader', then the market maker reduces the bid-ask spread. Market makers are confronted with an adverse selection problem if they do not know who, among the traders, has private information. The market makers therefore aim to optimize the bid-ask spread to maximize their profits. Consequently, the bid-ask price perfectly reflects the uncertainty and the risk of information asymmetry in the financial market: firms with a low level of these factors will be characterized by a wider bid-ask spread. Stoll (1989) estimates that the cost of information asymmetry is approximately $43 \%$ of the bid-ask spread in the NASDAQ and Lin, Sanger and Booth (1995) claim that is approximately $35 \%$ in the NYSE. Moreover, Menyah and Paudyal (2000) observed that it amounts to 47\% in the London Stock Exchange. Certification by a VC firm leads to a reduction in the costs connected with information asymmetry that has the effect of decreasing the bid-ask spread. Moreover, when there is a lack of transparency concerning the real value of a firm, we consider that there is a divergence of opinion among the investors. Shalen (1993) empirically demonstrated that price volatility, as an approximation of the level of information asymmetry, is strongly correlated with a divergence of anticipations. Because of the divergence of opinion of the noise traders, an increase in volatility is to be expected during the IPO, leading to an increase in the risks to which they are exposed. If certification by a VC firm enables a reduction in information asymmetry, then the IPO price volatility can also be reduced. If the level of information asymmetry is low, then it can be expected that the effect of certification/monitoring is more marked than that of adverse selection/grandstanding, bid-ask spread, information asymmetry cost and volatility. The following hypotheses have been developed to test the importance of the VC firm role during an IPO:

Hypothesis 1: If the certification/monitoring effect is stronger than that of adverse selection/grandstanding, then the bid/ask spread of the IPOs with VC firm involvement will be weaker.

Hypothesis 2: If the certification/monitoring effect is stronger than that of adverse selection/grandstanding, then the cost of the information asymmetry of IPOs with VC firm involvement will be weaker.

Hypothesis 3: If the certification/monitoring effect is stronger than that of adverse selection/grandstanding, then the volatility of the IPOs with VC firm involvement will be weaker. 


\section{RESEARCH DESIGN}

\subsection{Sample and Data}

The study covers a 14-year period, 2000-2013, and concerns the new issues in the three Eurolist segments in the NYSE Euronext regulated market. Data on the capital structure, the shares held by VC firms and the price of the offer were obtained from the IPO prospectuses required by the financial market authorities. Moreover, the high frequency stock market price data, the volume of negotiations and the bid-ask prices are from Euronext databases. An analysis of the available data provided a sample of 93 IPOs that had VC firm involvement. Each IPO financed by a VC firm was paired with an operation without a VC firm (year of IPO, sector and size) to create the second control sample. The majority of the sample was composed of technological firms: $87 \%$ of the sample firms were in the biotechnical, software, medical equipment, electricity and electronic accessories, and aerospace sectors. This result corroborated Amit, et al. (1998) and Lee and Wahal (2004) who found that firms financed by VC firms operate in sectors with a high level of information asymmetry, such as biotechnology and information technology.

Table 1. Sample and Descriptive Statistics

\begin{tabular}{l|r|r|r|r|r}
\hline & Median & \multicolumn{1}{c}{ SD } & \multicolumn{1}{c}{ Skewness } & \multicolumn{1}{c}{ Kurtosis } \\
\hline Panel A: Sample with VC $(\boldsymbol{n}=\mathbf{9 3})$ & & & & & \\
\hline Offer Size $(M \in)$ & 731.52 & 230.99 & 341.54 & 73.32 & 632.51 \\
\hline IPO Price $(\boldsymbol{\epsilon})$ & 23.38 & 17.95 & 16.32 & 5.92 & 19.32 \\
\hline MAR $(\%)$ & 12.28 & 11.64 & 15.23 & 3.26 & 9.79 \\
\hline Number of VC & 2.36 & 1.74 & 1.78 & 0.83 & 1.78 \\
\hline Shares owned by VC $(\%)$ & 13.91 & 15.31 & 5.97 & 2.78 & 15.78 \\
\hline Shares owned by founders $(\%)$ & 49.73 & 52.51 & 16.70 & 6.32 & 15.21 \\
\hline Age in years & 6.81 & 5.36 & 4.32 & 1.98 & 6.26 \\
\hline
\end{tabular}

Panel B: Sample without $V C(n=93)$

\begin{tabular}{|l|r|r|r|r|r}
\hline Offer size $(M €)$ & 811.41 & 401.86 & 320.75 & 76.11 & 592.44 \\
\hline IPO price $(\epsilon)$ & 20.38 & 17.02 & 15.65 & 4.68 & 21.32 \\
\hline MAR $(\%)$ & 14.52 & 12.26 & 17.31 & 4.28 & 11.08 \\
\hline Shares owned by founders $(\%)$ & 65.32 & 67.80 & 14.58 & 7.13 & 17.70 \\
\hline Age in years & 13.80 & 8.00 & 4.00 & 1.98 & 7.20 \\
\hline
\end{tabular}

Note: There is a total of 404 IPOs between 2001 and 2013 in the Euronext Paris stock exchange. The sample is limited to those in the Eurolist (A, B and C) that comprises three segments: Blue Chips includes firms with a market value greater than $€ 1$ billion; Mid cap firms with a market value between $€ 150$ million- $€ 1$ billion; and Small Caps firms with a market value less than $€ 150$ million.

Table 1 provides a statistical breakdown of the sample. The subscription price for IPOs with VC firm involvement is higher than for those without $\mathrm{VC}$ involvement, whereas their average size is smaller. The VC capital participation was an average of $13.91 \%$ for an average of $2.36 \mathrm{VC}$ firms per IPO. This result is lower than Barry, et al. (1990) and Megginson and Weiss (1991) observed in the American market (34.3\%-36.6\%). Given that control increases according to the number of shares held by the shareholder, this means that $\mathrm{VC}$ firms are likely to play a less important role in the French market. Finally, the underpricing can be defined as the yield between the closing prices on the first day of the negotiations and the IPO price, adjusted to the yield in the market.

Megginson and Weiss (1991) hypothesized that the participation of VC firms may reduce both IPO costs and underpricing. Moreover, Barry et al. (1990) pointed out that the control exercised by the VC firms also helps to minimize underpricing. However, Lee and Wahal (2004) confirmed that underpricing is higher for IPOs with VC firm involvement, as the VC firms are anxious to maintain their good reputation in the market. The current results confirm these assertions: for operations with $\mathrm{VC}$ firm involvement, the underpricing amounts to $14.52 \%$, whereas it amounts to $12.28 \%$ for those without VC involvement. Consequently, in the French market, VC firms try to raise funds rather than carrying out control or certification activities.

\subsection{Measures of Information Asymmetry}

We adopted several microstructure measurements to ascertain the degree of information asymmetry including the bid-ask price spread, the information asymmetry component that concerns the spread and the volatility. 


\subsubsection{Effective Spread}

The bid-ask price spread is the difference between the lowest purchasing price and the highest sale price. Demsetz (1968) takes the bid-ask spread as a recompense granted to the market-makers for them to undertake immediate negotiations. It is one of the main transaction costs for investors. We estimated the effective spread $S_{i, d}$, and the relative effective spread ${ }^{1} R S_{i, d}$ in the same way as Hebb and MacKinnon (2004):

$$
S_{i, d}=2 \times\left|P_{i, d}-M P_{i, d}\right| \text { and } R S_{i, d}=\frac{2 \times\left|P_{i, d}-M P_{i, d}\right|}{M P_{i, d}}
$$

where $P_{i, j}$ designates the firm's closing price $i$ on day $j$, and $M P_{i, d}$ represents the middle of the bid-ask spread defined as $\left(a s k_{i, d}+b i d_{i, d}\right) / 2$. The terms $a s k_{i, d}$ and $b i d_{i, d}$ respectively represent the required closing price and that of the offer for the firm $i$ on day $d$.

\subsubsection{Information Asymmetry Component in the Spread}

This involves compensating the market-makers for negotiations with the informed traders who have the best information. The market-makers try to enlarge the spread during the periods where there is strong information asymmetry. To measure the cost of the information asymmetry in the bid-ask price spread, we followed the method by George, Kaul and Nimalendran (1991). This is defined as $\phi_{i d}=1-\pi_{i, d}$ and indicates the unobservable proportion of the quoted bid-ask spread due to adverse selection resulting from the information asymmetry of the share $i$ on day $d . \pi_{i, d}$ represents unobservable proportion of the quoted spread due to order-processing costs:

$$
\pi_{i, d}=\frac{2 \times \sqrt{-\operatorname{Cov}\left(R D_{i, t}, R D_{i, t-1}\right)}}{S_{i, d}}
$$

where $R D_{i, t}=R_{i T t}-R_{i B t}, R_{i T t}$ represents 10 minutes of intraday yield for the firm $i$ according to transaction price $T$ in a lapse of time $t-1$ and $t, R_{i B t}$ represents 10 minutes of intraday yield calculated according to the bid price (Bid) $B$, $S_{i, d}$ is the arithmetical average over 27 periods of 10 minutes per day for the firm $i$ and $\operatorname{Cov}\left(R D_{i, t}, R D_{i, t-1}\right)$ represents the covariance of the statistical series $R D_{i, t}$.

\subsubsection{Volatility}

Unlike in the classical approach that uses the closing price to calculate the security yield, Garman and Klass (1980) propose a more relevant improved estimator that considers the high $(H)$, low $(L)$, opening $(O)$ and closing $(C)$ prices since the share price is supposed to follow a Brownian motion without breaks. We estimated the volatility according to this approach using the following formula:

$$
\sigma_{i, d}^{2}=0,511(a-b)^{2}-0,019[x(a+b)-2 a b]-0,383 x^{2}
$$

where $a=\ln (H / O), b=\ln (L / O), \ln (C / O)$ and $\sigma_{i, d}^{2}$ represents the volatility of firm $i$ on day $d$. According to Garman and Klass (1980), the coefficients are fixed in such a way that the estimator is unbiased with minimal variance.

\subsection{The Basic Regression Model}

Consider that the presence of a VC firm enables the information asymmetry to be reduced between the issuer and the individual investors; hence, it is likely that there will be a decrease in the bid-ask spread, the cost of information asymmetry and the volatility. The particular nature of a VC firm is likely to influence the microstructure characteristics of the financial markets. We tested the regression in the following cross-section.

\footnotetext{
${ }^{1}$ Corresponds to the difference (relative to the middle of the spread) in absolute value between the price at which a transaction has been carried out and the middle of the spread. 


$$
\begin{aligned}
& Y_{i}=\alpha_{0}+\alpha_{1} \text { VC }_{i}+\alpha_{2} \text { Board }_{i}+\alpha_{3} \text { Nbr }_{i}+\alpha_{4} \text { Share }_{i}+\alpha_{5} \text { MAR }_{i}+\alpha_{6} \text { LnMV }_{i}+ \\
& \alpha_{7}\left(\frac{1}{\text { Age }}\right)_{i}+\alpha_{8} \text { Earnings }_{i}+\alpha_{9} N \operatorname{Tr}_{i}+\varepsilon_{i}
\end{aligned}
$$

where $Y_{i}$ represents the average of the bid-ask spreads $\left(R S_{i}\right) ; \phi_{i}$ represents the information asymmetry and $\sigma_{i}^{2}$ represents the volatility, both between days $1-30 ; V C_{i}$ (within the capital) and Board $_{i}$ (seat on the board) are two binary variables; Share $_{i}$ represents the share held by the VC firm; $N b r_{i}$ indicates the number of VC firms within the capital; $M A R_{i}$ represents the observed yield on the first day adjusted to that of the market; $\ln M V_{i}$ is the logarithm of the firm's equities market value; $1 / \mathrm{Age}_{i}$ represents the inverse of the age of the firm in years on the day of its IPO; Earnings $_{i}$ represents the earnings per share during the year before the firm's IPO divided by the average observed closing price on the first day; and $N T r_{i}$ represents the average number of trades between days 1 and 30 following the IPO.

\section{EMPIRICAL RESULTS AND DISCUSSION}

To test the hypotheses, we first present the different microstructure characteristics of the sample. This is followed by the presentation of and a discussion on the empirical results.

\subsection{Comparison of the Subsample Microstructures}

I compared both subsamples in terms of their effective relative spread, their information asymmetry costs and their volatility using Mann-Whitney's nonparametric test and the classic t-test. Table 2 presents the panel data for both subsamples on the relative differences of the effective spread. Panel A presents the average of the daily spread between days 1 and 5 after the start of negotiations, and Panel B presents the average for the different periods of time. With the exception of day 5 , the results do not show any significant difference in the relative effective spread between the subsamples. The results for the first two time periods in Panel B (days 1-10 and days 11-21) show a lower relative effective spread for the IPOs with VC firm involvement, whereas the contrary is true for the third time period (days 21-30). These results allow me to reject the first hypothesis, where the presence of a VC firm enables a reduction in the level of information asymmetry. However, IPOs with VC firm involvement are characterized by a relative effective spread that is lower during negotiations.

\begin{tabular}{|c|c|c|c|}
\hline & IPOs with VC & IPOs without VC & Difference* \\
\hline \multicolumn{4}{|c|}{ Panel A: Daily measure } \\
\hline Day 1 & 0.003 & 0.004 & $\begin{array}{r}-0.517 \\
(-0.70)\end{array}$ \\
\hline Day 2 & 0.006 & 0.007 & $\begin{array}{c}0.062 \\
(0.15)\end{array}$ \\
\hline Day 3 & 0.008 & 0.007 & $\begin{array}{c}-0.386 \\
(-1.10)\end{array}$ \\
\hline Day 4 & 0.246 & 0.010 & $\begin{array}{c}1.068 \\
(1.133)\end{array}$ \\
\hline Day 5 & 0.006 & 0.013 & $\begin{array}{l}-2.201^{\alpha} \\
(-2.84)\end{array}$ \\
\hline \multicolumn{4}{|c|}{ Panel B: Interval measure } \\
\hline Days $1-10$ & 0.005 & 0.011 & $\begin{array}{c}-0.874 \\
(-0.82)\end{array}$ \\
\hline Days $11-20$ & 0.010 & 0.036 & $\begin{array}{r}0.169 \\
(-0.45)\end{array}$ \\
\hline Days 21-30 & 0.008 & 0.007 & $\begin{array}{c}0.727 \\
(0.84) \\
\end{array}$ \\
\hline
\end{tabular}

Table 2. Relative effective spread

Note: * Z-statistic of Mann-Whitney U test. This nonparametric test is used to compare two independent small samples; t-statistics are reported between brackets: $\alpha, \beta$ and $\gamma$ respectively mean a significant coefficient at the level of $1 \%, 5 \%$ and $10 \%$. 
Table 3 presents the empirical results for the information asymmetry costs in both subsamples. Generally, the costs are lower for IPOs with VC firm involvement in the first few days following the IPO. All three Panel B time period results show that the information asymmetry costs of IPOs with VC firm involvement are not lower than those without. Consequently, we reject the second hypothesis. Volatility is higher for IPOs with VC firm involvement than those without, but this difference is less marked and not significant.

Table 3. Information asymmetry analysis

\begin{tabular}{|c|c|c|c|}
\hline & IPOs with VC & IPOs without VC & Difference \\
\hline \multicolumn{4}{|c|}{ Panel A: Daily measure } \\
\hline Day 1 & 0.236 & 0.300 & $\begin{array}{r}0.208 \\
(-0.26)\end{array}$ \\
\hline Day 2 & 0.302 & 0.331 & $\begin{array}{c}-0.140 \\
(-0.01)\end{array}$ \\
\hline Day 3 & 0.304 & 0.382 & $\begin{array}{c}-0.178 \\
(-0.35)\end{array}$ \\
\hline Day 4 & 0.603 & 0.494 & $\begin{array}{c}1.706^{\beta} \\
(1.14)\end{array}$ \\
\hline Day 5 & 0.539 & 0.610 & $\begin{array}{c}-0.104 \\
(0.19)\end{array}$ \\
\hline
\end{tabular}

Panel B: Interval measure

\begin{tabular}{|c|c|c|c|}
\hline Days $1-10$ & 0.440 & 0.406 & $\begin{array}{r}0.101 \\
(0.79)\end{array}$ \\
\hline Days $11-20$ & 0.468 & 0.490 & $\begin{array}{l}-1.006 \\
(-0.92)\end{array}$ \\
\hline Days $21-30$ & 0.495 & 0.431 & $\begin{array}{r}1.068 \\
(1.07) \\
\end{array}$ \\
\hline
\end{tabular}

Note: * Z-statistic of Mann-Whitney U test. This nonparametric test is used to compare two independent small samples; t-statistics are reported between brackets: $\alpha, \beta$ and $\gamma$ respectively mean a significant coefficient at the level of $1 \%, 5 \%$ and $10 \%$.

Table 4 shows that the volatility of IPOs with VC firm involvement is higher in each Panel B time period than in those without VC firm involvement. Consequently, we reject the third hypothesis. The different results (spread and relative information asymmetry) reject the hypothesis that the role of certification/monitoring dominates that of the adverse selection/grandstanding of VC firms in the French market. The results prove that the degree of information asymmetry in IPOs with VC firm involvement, perceived by the financial market, is not lower than those without VC firm involvement as far as the relative effective spread, the information asymmetry costs and the volatility are concerned. The results also indicate that a reduction in information asymmetry because of the effect of certification/ monitoring by the VC firm may be largely compensated for by the VC firm's adverse selection/grandstanding effect. 
Table 4. Price volatility analysis

\begin{tabular}{|c|c|c|c|}
\hline & IPOs with CR & IPOs without CR & Difference \\
\hline \multicolumn{4}{|c|}{ Panel A: Daily measure } \\
\hline Day 1 & 0.006 & 0.005 & $\begin{array}{c}1.001 \\
(-0.02)\end{array}$ \\
\hline Day 2 & 0.004 & 0.003 & $\begin{array}{c}0.617 \\
(0.79)\end{array}$ \\
\hline Day 3 & 0.004 & 0.003 & $\begin{array}{l}0.700 \\
(0.58)\end{array}$ \\
\hline Day 4 & 0.003 & 0.003 & $\begin{array}{l}0.198 \\
(0.05)\end{array}$ \\
\hline Day 5 & 0.004 & 0.003 & $\begin{array}{r}0.533 \\
(1.01) \\
\end{array}$ \\
\hline \multicolumn{4}{|c|}{ Panel B: Interval measure } \\
\hline Days $1-10$ & 0.003 & 0.003 & $\begin{array}{l}0.601 \\
(0.53)\end{array}$ \\
\hline Days $11-20$ & 0.003 & 0.002 & $\begin{array}{l}1.024 \\
(1.40)\end{array}$ \\
\hline Days $21-30$ & 0.003 & 0.002 & $\begin{array}{r}0.803 \\
(0.44) \\
\end{array}$ \\
\hline
\end{tabular}

Note: * Z-statistic of Mann-Whitney U test. This nonparametric test is used to compare two independent small samples; t-statistics are reported between brackets: $\alpha, \beta$ and $\gamma$ respectively mean a significant coefficient at the level of $1 \%, 5 \%$ and $10 \%$.

\subsection{Analysis of Information Asymmetry and Volatility}

To gain a better understanding of the factors likely to influence the bid-ask spread, information asymmetry and volatility, we also analyzed the main IPO characteristics. Table 5 shows the results relating to the relations between bid-ask spreads and the factors associated with IPO characteristics. In accordance with the results presented in section 4.1, we observe that there is no relationship between financing on the part of the VC firm and the bid-ask spreads; this enables me to again reject the first hypotheses. This may be because of the particular characteristics of the French stock market, particularly the dominance of small investors. The bid-ask spread in this market is not affected by information on share prices, as most such investors are not informed. 
Table 5. Factors Affecting the Relative Effective Spread $\left(R S_{i}\right)$

\begin{tabular}{|c|c|c|c|c|c|}
\hline Dependent variables: & Model (1) & Model (2) & Model (3) & Model (4) & Model (5) \\
\hline Constant & $\begin{array}{l}-0.139^{\beta} \\
(-2.06)\end{array}$ & $\begin{array}{l}-0.174^{\gamma} \\
(-2.74)\end{array}$ & $\begin{array}{l}-0.179^{\gamma} \\
(-2.68)\end{array}$ & $\begin{array}{l}-0.180^{\gamma} \\
(-2.83)\end{array}$ & $\begin{array}{l}-0.226^{\gamma} \\
(-2.72)\end{array}$ \\
\hline MAR & $\begin{array}{c}0.186 \\
(1.20)\end{array}$ & $\begin{array}{c}0.201 \\
(1.00)\end{array}$ & $\begin{array}{c}0.218 \\
(1.09)\end{array}$ & $\begin{array}{c}0.183 \\
(1.19)\end{array}$ & $\begin{array}{l}0.2625 \\
(1.37)\end{array}$ \\
\hline Shares & & & & $\begin{array}{l}0.086^{\alpha} \\
(1.73)\end{array}$ & $\begin{array}{l}-0.027^{\alpha} \\
(-1.65)\end{array}$ \\
\hline $\mathrm{VC}$ & $\begin{array}{c}0.165 \\
(0.93)\end{array}$ & & & & $\begin{array}{c}0.356 \\
(1.25)\end{array}$ \\
\hline Boards & & $\begin{array}{c}0.091 \\
(0.583)\end{array}$ & & & $\begin{array}{r}0.027 \\
(0.63)\end{array}$ \\
\hline $\mathrm{Nbr}$ & & & $\begin{array}{c}-0.026 \\
(-0.195)\end{array}$ & & $\begin{array}{c}-0.201 \\
(-1.24)\end{array}$ \\
\hline $\operatorname{Ln}(\mathrm{MV})$ & $\begin{array}{c}-0.207 \\
(-0.84)\end{array}$ & $\begin{array}{c}-0.301 \\
(-1.224)\end{array}$ & $\begin{array}{c}-0.236 \\
(-1.098)\end{array}$ & $\begin{array}{c}-0.256 \\
(-1.26)\end{array}$ & $\begin{array}{l}-0.302 \\
(-1.22)\end{array}$ \\
\hline 1/Age & $\begin{array}{c}-0.003 \\
(-0.43)\end{array}$ & $\begin{array}{c}-0.065 \\
(-0.434)\end{array}$ & $\begin{array}{c}-0.014 \\
(-0.057)\end{array}$ & $\begin{array}{c}-0.067 \\
(-0.247)\end{array}$ & $\begin{array}{c}0.116 \\
(0.63)\end{array}$ \\
\hline Earning & $\begin{array}{c}0.065 \\
(0.50)\end{array}$ & $\begin{array}{c}0.038 \\
(0.236)\end{array}$ & $\begin{array}{c}0.015 \\
(0.083)\end{array}$ & $\begin{array}{c}0.036 \\
(0.326)\end{array}$ & $\begin{array}{r}0.072 \\
(0.32)\end{array}$ \\
\hline $\mathrm{NTr}$ & $\begin{array}{c}-0.019 \\
(-0.11)\end{array}$ & $\begin{array}{c}0.016 \\
(0.054)\end{array}$ & $\begin{array}{c}0.001 \\
(0.003)\end{array}$ & $\begin{array}{c}-0.006 \\
(-0.009)\end{array}$ & $\begin{array}{r}0.025 \\
(0.02)\end{array}$ \\
\hline Adjusted $R^{2}$ & 0.153 & 0.173 & 0.185 & 0.199 & 0.208 \\
\hline$F$-Stat. & $25.99^{\gamma}$ & $24.34^{\gamma}$ & $35.19^{\gamma}$ & $28.41^{\gamma}$ & $14.23^{\gamma}$ \\
\hline $\mathrm{N}$ & 186 & 186 & 186 & 186 & 186 \\
\hline
\end{tabular}

$\alpha, \beta$ and $\gamma$ respectively mean a significant coefficient at the level of $1 \%, 5 \%$ and $10 \%$.

Table 6 shows the results of the relationship between information asymmetry costs and the characteristics of an IPO. Model (2) indicates that the presence of a $\mathrm{VC}$ firm within the board of directors has a positive impact on the information asymmetry cost. This result is in accordance with those in section 4.1 on IPO information asymmetry. Once again, IPOs that involve a VC firm do not present a lower level of information asymmetry than those with no VC firm involvement, thereby rejecting the second hypothesis. Table 5 also shows that, because of better transparency, the information asymmetry costs incurred by large firms are lower than those for small firms. Moreover, the information asymmetry costs are positively correlated with the degree of underpricing. This result enables me to maintain the hypothesis concerning the information asymmetry of IPOs whereby the issuers of securities are ready to accept a low subscription price in the case of limited uncertainty as to the conditions of the market demand (Beatty and Ritter (1986) and Michaely and Shaw (1994)). 
Table 6. Factors affecting the Asymmetric information $\left(\phi_{i}\right)$

\begin{tabular}{|c|c|c|c|c|c|}
\hline Dependent variables: & Model (1) & Model (2) & Model (3) & Model (4) & Model (5) \\
\hline Constant & $\begin{array}{l}-0.213^{\beta} \\
(-2.22)\end{array}$ & $\begin{array}{l}-0.192^{\gamma} \\
(-2.69)\end{array}$ & $\begin{array}{l}-0.201^{\gamma} \\
(-2.74)\end{array}$ & $\begin{array}{l}-0.193^{\gamma} \\
(-2.81)\end{array}$ & $\begin{array}{l}-0.220^{\gamma} \\
(-2.79)\end{array}$ \\
\hline MAR & $\begin{array}{c}0.285^{\beta} \\
(2.31)\end{array}$ & $\begin{array}{c}0.297^{\beta} \\
(2.51)\end{array}$ & $\begin{array}{c}0.294^{\beta} \\
(2.25)\end{array}$ & $\begin{array}{c}0.283^{\beta} \\
(2.19)\end{array}$ & $\begin{array}{c}0.312^{\beta} \\
(2.68)\end{array}$ \\
\hline Shares & & & & $\begin{array}{c}0.164 \\
(1.21)\end{array}$ & $\begin{array}{c}0.237 \\
(0.15)\end{array}$ \\
\hline VC & $\begin{array}{c}0.216 \\
(1.45)\end{array}$ & & & & $\begin{array}{c}0.196 \\
(0.59)\end{array}$ \\
\hline $\mathrm{CA}$ & & $\begin{array}{c}0.450^{\beta} \\
(2.38)\end{array}$ & & & $\begin{array}{r}0.473 \\
(1.54)\end{array}$ \\
\hline $\mathrm{Nbr}$ & & & $\begin{array}{c}0.037 \\
(0.39)\end{array}$ & & $\begin{array}{c}-0.221 \\
(-1.49)\end{array}$ \\
\hline $\operatorname{Ln}(\mathrm{MV})$ & $\begin{array}{l}-0.704^{\alpha} \\
(-2.84)\end{array}$ & $\begin{array}{l}-0.603^{\alpha} \\
(-3.32)\end{array}$ & $\begin{array}{l}-0.591^{\alpha} \\
(-2.89)\end{array}$ & $\begin{array}{l}-0.630^{\alpha} \\
(-3.01)\end{array}$ & $\begin{array}{l}-0.605^{\alpha} \\
(-3.38)\end{array}$ \\
\hline 1/Age & $\begin{array}{c}0.186 \\
(1.26)\end{array}$ & $\begin{array}{c}0.131 \\
(0.80)\end{array}$ & $\begin{array}{c}0.189 \\
(1.060)\end{array}$ & $\begin{array}{c}0.155 \\
(0.95)\end{array}$ & $\begin{array}{c}0.247 \\
(1.34)\end{array}$ \\
\hline Earning & $\begin{array}{c}0.152 \\
(1.18)\end{array}$ & $\begin{array}{r}0.211 \\
(1.42)\end{array}$ & $\begin{array}{c}0.102 \\
(0.68)\end{array}$ & $\begin{array}{c}0.157 \\
(0.980)\end{array}$ & $\begin{array}{r}0.199 \\
(1.28)\end{array}$ \\
\hline $\mathrm{NTr}$ & $\begin{array}{c}-0.066 \\
(-0.450)\end{array}$ & $\begin{array}{c}0.028 \\
(0.230)\end{array}$ & $\begin{array}{c}-0.043 \\
(-0.24)\end{array}$ & $\begin{array}{c}-0.023 \\
(-0.127)\end{array}$ & $\begin{array}{l}0.083 \\
0.460\end{array}$ \\
\hline Adjusted $R^{2}$ & 0.103 & 0.113 & 0.145 & 0.150 & 0.163 \\
\hline$F$-Stat. & $18.58^{\gamma}$ & $17.52^{\gamma}$ & $21.08^{\gamma}$ & $19.04^{\gamma}$ & $19.32^{\gamma}$ \\
\hline $\mathrm{N}$ & 186 & 186 & 186 & 186 & 186 \\
\hline
\end{tabular}

$\alpha, \beta$ and $\gamma$ respectively mean a significant coefficient at the level of $1 \%, 5 \%$ and $10 \%$.

Table 5 (Panel C) shows that there is no relationship between the presence of a VC firm and the IPO volatility, thereby rejecting hypothesis 3. Although numerous studies on the American market show that the presence of VC firms reduces the IPO information asymmetry costs, my empirical results on the French market reject this hypothesis. Consequently, the monitoring carried out by VC firms has no effect during the IPO process in the French market.

Table 7. Factors affecting the Price volatility $\left(\sigma_{i}^{2}\right)$

\begin{tabular}{|c|c|c|c|c|c|}
\hline Dependent variables: & Model (1) & Model (2) & Model (3) & Model (4) & Model (5) \\
\hline Constant & $\begin{array}{l}-0.129^{\beta} \\
(-1.87)\end{array}$ & $\begin{array}{l}-0.154^{\gamma} \\
(-2.61)\end{array}$ & $\begin{array}{l}-0.151^{\gamma} \\
(-2.74)\end{array}$ & $\begin{array}{l}-0.163^{\gamma} \\
(-2.76)\end{array}$ & $\begin{array}{l}-0.171^{\gamma} \\
(-2.79)\end{array}$ \\
\hline MAR & $\begin{array}{r}0.121 \\
(0.70)\end{array}$ & $\begin{array}{r}0.121 \\
(0.74)\end{array}$ & $\begin{array}{c}0.068 \\
(0.44)\end{array}$ & $\begin{array}{c}0.075 \\
(0.45)\end{array}$ & $\begin{array}{c}0.069 \\
(0.39)\end{array}$ \\
\hline Shares & & & & $\begin{array}{c}0.303 \\
(1.47)\end{array}$ & $\begin{array}{c}0.261 \\
(0.980)\end{array}$ \\
\hline $\mathrm{VC}$ & $\begin{array}{c}0.139 \\
(0.806)\end{array}$ & & & & $\begin{array}{c}-0.326 \\
(-1.07)\end{array}$ \\
\hline Boards & & $\begin{array}{c}0.298 \\
(1.60)\end{array}$ & & & $\begin{array}{c}0.374 \\
(1.41)\end{array}$ \\
\hline $\mathrm{Nbr}$ & & & $\begin{array}{c}0.198 \\
(1.12)\end{array}$ & & $\begin{array}{c}0.091 \\
(0.401)\end{array}$ \\
\hline $\operatorname{Ln}(\mathrm{MV})$ & $\begin{array}{c}-0.301 \\
(-1.39)\end{array}$ & $\begin{array}{l}-0.288^{\gamma} \\
(-1.73)\end{array}$ & $\begin{array}{c}-0.250 \\
(-1.25)\end{array}$ & $\begin{array}{c}-0.301 \\
(-1.38)\end{array}$ & $\begin{array}{l}-0.306^{\gamma} \\
(-1.65)\end{array}$ \\
\hline 1/Age & $\begin{array}{c}0.204 \\
(1.50)\end{array}$ & $\begin{array}{c}0.136 \\
(1.10)\end{array}$ & $\begin{array}{c}0.162 \\
(0.81)\end{array}$ & $\begin{array}{c}0.205 \\
(1.103)\end{array}$ & $\begin{array}{c}0.104 \\
(0.307)\end{array}$ \\
\hline Earning & $\begin{array}{c}-0.081 \\
(-0.51)\end{array}$ & $\begin{array}{l}-0.021 \\
(-0.11)\end{array}$ & $\begin{array}{c}-0.057 \\
(-0.39)\end{array}$ & $\begin{array}{c}-0.042 \\
(0.36)\end{array}$ & $\begin{array}{c}0.010 \\
(0.08)\end{array}$ \\
\hline $\mathrm{NTr}$ & $\begin{array}{l}0.599^{\alpha} \\
(3.24)\end{array}$ & $\begin{array}{c}0.601^{\alpha} \\
(3.54)\end{array}$ & $\begin{array}{c}0.621^{\alpha} \\
(2.99)\end{array}$ & $\begin{array}{c}0.701^{\alpha} \\
(3.50)\end{array}$ & $\begin{array}{l}0.815^{\alpha} \\
(3.38)\end{array}$ \\
\hline Adjusted $R^{2}$ & 0.135 & 0.190 & 0.200 & 0.261 & 0.280 \\
\hline$F$-Stat. & $20.95^{\gamma}$ & $21.45^{\gamma}$ & $21.85^{\gamma}$ & $23.54^{\gamma}$ & $24.32^{\gamma}$ \\
\hline $\mathrm{N}$ & 186 & 186 & 186 & 186 & 186 \\
\hline
\end{tabular}




\section{CONCLUSION}

The majority of studies on VC firms concentrate on the North American market; however, this study focuses on the French market where such activities are experiencing startup difficulties. The study examines whether the presence of a VC firm during an IPO enables a reduction in information asymmetry - between the insiders and the outsiders using high frequency data from the French stock exchange. The results do not show a significant difference between the two subsamples as far as the bid-ask spreads are concerned. The information asymmetry costs for the IPOs with $\mathrm{VC}$ firm involvement are no lower than for those with $\mathrm{VC}$ firm involvement, whereas the price volatility for the IPOs with VC firm involvement is greater than for those without VC firm involvement. Consequently, the empirical results show that the reduction in information asymmetry caused by the VC firms' certification/monitoring effect on the IPO can be largely compensated for by the adverse selection/grandstanding effect.

Moreover, the study concludes that underpricing positively influences the information asymmetry cost. In fact, IPOs financed by $\mathrm{VC}$ firms are characterized by considerable underpricing that significantly increases their information asymmetry costs. Consequently, the presence of $\mathrm{VC}$ within the firm does not enable a reduction in the amount of asymmetry between informed and uninformed investors. This result differs from previous studies on the role played by VC firms in the North American market. There could be several reasons for the divergence between this study and previous ones. First, there is a relatively low level of participation on the part of VC investors in French IPOs. The share of the capital held by VC firms before a French IPO is an average of $9.43 \%$, considerably lower than the $34.3 \%$ observed by Barry et al. (1990) in the American markets. Consequently, VC firms are unable to exercise active and intensive control on the firms that turn towards the financial market. Second, VC firms are relatively new to the French market. Grandstanding motives may incite VC firms to participate in IPOs to create a good image against investors and to facilitate future fund raising, rather than to help firms grow. Generally, there is no certification role on the part of VC firms in the French market. Finally, the majority of the exchanges in this market are made by individual investors; this diminishes the potential of $\mathrm{VC}$ firms to reduce the level of information asymmetry during the IPO process.

\section{AUTHOR BIOGRAPHY}

Tarek Miloud is Professor of Finance at INSEEC Business School, where he has been since 2005. During 19992004, he was an assistant Professor at the Louvain School of Management. He received a M.Sc. from the Lovain School of Management in 1999, and a Ph.D. in Finance from the Catholic University of Louvain at Louvain-laNeuve in 2003.

His current research interests are globally on corporate finance and particularly include corporate governance and Initial Public Offering. In corporate governance Professor Tarek MILOUD has analyzed if different corporate governance mechanisms like managerial compensation, board composition, shareholder rights or product market competition act as complements or substitutes to alleviate problems due to the separation of ownership and control. $\mathrm{He}$ has also investigated the relationship between ownership and firm performance around IPO. His papers have been published in several peer reviewed international academic journals.

\section{REFERENCES}

Amit, R., J. Brander, and C. Zott, 1998, Why do venture capital firms exist? Theory and canadian evidence, Journal of Business Venturing 13(6), 441-466.

Arikawa, Y., and G. Imad'eddine, 2010, Venture capital affiliation with underwriters and the underpricing of initial public offerings in japan, Journal of Economics and Business 62(6), 502-516.

Barry, C., C. Muscarella, J. Peavy, and M. Vetsuypens, 1990, The role of venture capital in the creation of public companies: Evidence from the going-public process, Journal of Financial Economics 27(2), 447-471.

Beatty, R., and J. Ritter, 1986, Investment banking, reputation, and the underpricing of initial public offerings, Journal of Financial Economics 15(1-2), 213-232.

Booth, R., and L. Smith, 1986, Capital raising, underwriting and the certification hypothesis, Journal of Financial Economics $15(1-2), 262-281$.

Brav, A., and P. Gompers, 1997, Myth or reality? The long-run underperformance of initial public offerings: Evidence from venture and nonventure capital-backed companies, The Journal of Finance 52(5), 1791-1821. 
Chemmanur, T.J., and K. Krishnan, 2012, Heterogeneous beliefs, short sale constraints, and the economic role of the underwriter in ipos, Financial Management 41(4), 769-811.

Copeland, T., and D. Galai, 1983, Information effects on the bid-ask spread, The Journal of Finance 38(5), 1457-1469.

Demsetz, H., 1968, The cost of transacting, The Quarterly Journal of Economics 82(1), 33-53.

Elston, A., and J. Yang, 2010, Venture capital, ownership structure, accounting standards and ipo underpricing: Evidence from germany, Journal of Economics and Business 62(6), 517-536.

Francis, B., and I. Hasan, 2001, The underpricing of venture and non-venture capital ipos: An empirical investigation, Journal of Financial Services Research 19(2/3), 93-113.

Garman, M., and M. Klass, 1980, On the estimation of security price volatilities from historical data, The Journal of Business 53(1), 67-78.

George, T., G. Kaul, and M. Nimalendran, 1991, Estimation of the bid - ask spread and its components: A new approach, Review of Financial Studies 4(4), 623-656.

Glosten, L., and P. Milgrom, 1985, Bid, ask and transaction prices in a specialist market with heterogeneously informed traders, Journal of Financial Economics 14(1), 71-100.

Gompers, P., 1996, Grandstanding in the venture capital industry, Journal of Financial Economics 42(1), 133-156.

Gompers, P., and J. Lerner, 2004. The venture capital cycle, $2^{\text {nd }} e d$. (The Massachusetts Institute of Technology Press, Cambridge).

Hebb, G., and G. MacKinnon, 2004, Valuation uncertainty and ipos: Investment bank versus commercial bank underwriters, Journal of Economics and Finance 28(1), 68-87.

Jain, B., and O. Kini, 1995, Venture capitalist participation and the post-issue operating performance of ipo firms, Managerial and Decision Economics 16(6), 593-606.

Lee, P., and S. Wahal, 2004, Grandstanding, certification and the underpricing of venture capital backed ipos, Journal of Financial Economics 73(2), 375-407.

Lin, J., G. Sanger, and G. Booth, 1995, Trade size and components of the bid-ask spread, Review of Financial Studies 8(4), 11531183 .

Loughran, T., and J. Ritter, 2002, Why don't issuers get upset about leaving money on the table in ipos?, Review of Financial Studies 15(2), 413-433.

Loughran, T., and J. Ritter, 2004, Why has ipo underpricing changed over time?, Financial Management 33(3), 5-37.

Madhavan, A., 2000, Market microstructure: A survey, Journal of Financial Markets 3(3), 205-58.

Megginson, W., and K.A. Weiss, 1991, Venture capitalists certification in initial public offerings, The Journal of Finance 46(3), $135-151$.

Menyah, K., and K. Paudyal, 2000, The components of bid-ask spreads on the london stock exchange, Journal of Banking \& Finance 24(11), 1767-1785.

Michaely, R., and W. Shaw, 1994, The pricing of initial public offerings: Tests of adverse selection and signaling theories, Review of Financial Studies 7(2), 279-319.

O'Hara, M., 1999, Making market microstructure matter, Financial Management 28(2), 83-90.

Peggy, M., and S. Wahal, 2004, Grandstanding, certification and the underpricing of venture capital backed ipos, Journal of Financial Economics 73(2), 375-407.

Ritter, J., and I. Welch, 2002, A review of ipo activity, pricing, and allocations, The Journal of Finance 57(4), $1795-1828$.

Rossetto, S., 2008, The price of rapid exit in venture capital-backed ipos, Annals of Finance 4(1), 29-53.

Rossetto, S., 2013, Ipo activity and information in secondary market prices, Annals of Finance 9(4), 667-687.

Sahlman, W., 1990, The structure and governance of venture-capital organizations, Journal of Financial Economics 27(2), 473521.

Shalen, C., 1993, Volume, volatility, and the dispersion of beliefs, The Review of Financial Studies 6(2), 405-434.

Stein, J., 2002, Information production and capital allocation: Decentralized versus hierarchical firms, The Journal of Finance 57(5), 1891-1921.

Stoll, H., 1989, Inferring the components of the bid-ask spread: Theory and empirical tests, The Journal of Finance 44(1), 115134.

Tirole, J., 2006. The theory of corporate finance (Princeton University Press, New Jersey).

Wang, C., K. Wang, and Q. Lu, 2003, Effects of venture capitalists' participation in listed companies, Journal of Banking and Finance 27(10), 2015-2034. 


\section{NOTES}

